RESEARCH ARTICLE

\title{
Reproductive Health Problems in Adolescents in Banten Province
}

\author{
Ismiyati, ${ }^{1}$ Udin Sabarudin, ${ }^{2}$ Tuti Wahmurti, ${ }^{3}$ Farid Husin, ${ }^{2}$ \\ Susi Susanah, ${ }^{4}$ Deni Kurniadi Sunjaya ${ }^{5}$ \\ ${ }^{1}$ Department of Midwifery, Politeknik Kesehatan Kementerian Kesehatan Banten, Serang, Indonesia, \\ ${ }^{2}$ Department of Obstetrics and Gynecology, ${ }^{3}$ Department of Psychiatry, Faculty of Medicine, \\ Universitas Padjadjaran, Bandung, Indonesia, ${ }^{4}$ Department of Child Health, \\ Dr. Hasan Sadikin General Hospital, Bandung, Indonesia, ${ }^{5}$ Department of Public Health, \\ Faculty of Medicine, Universitas Padjadjaran, Bandung, Indonesia
}

\begin{abstract}
Teenagers are the next generation that needs to be the center of attention. Physical and mental development in adolescents occurs rapidly. The process of changing times with free association arises causing debate about their reproductive health. The purpose of this study was to determine the reproductive health problems of adolescents in Banten province. This study used a qualitative design and constructivism paradigm. The research method was using the in-depth interview guideline instrument with 11 informants conducted in Banten province in JanuaryJune 2017. Qualitative data analysis using content analysis. The results showed that environmental factors such as family, relationships, health workers, and the availability of prostitution practice were trigger teenagers' problems. The environment did not support them to learn about sexuality makes them seek information from sources that cannot be justified. This practice made adolescents have inappropriate knowledge about adolescent reproductive health. The availability of prostitution practice was a unique highlight for those who can channel their curiosity in fulfilling their sexual desires. In conclusions, adolescent reproductive health problems in Banten province consisted of premarital sex behavior, teenage pregnancy, teenage marriage, youth delivery, sexually transmitted diseases, and abnormal sexual behavior. These problems arise due to factors of knowledge, environment, and family economic status.
\end{abstract}

Key words: Adolescent, reproductive health, sexuality

\section{Permasalahan Kesehatan Reproduksi pada Remaja di Provinsi Banten}

\begin{abstract}
Abstrak
Remaja merupakan generasi penerus yang perlu menjadi pusat perhatian. Perkembangan fisik dan mental pada remaja terjadi secara pesat. Proses perubahan zaman dengan pergaulan bebas memicu timbulnya permasalahan kesehatan reproduksi pada mereka. Tujuan penelitian ini mengetahui permasalahan kesehatan reproduksi remaja di Provinsi Banten. Penelitian ini menggunakan desain kualitatif dan paradigma konstruktivisme. Metode penelitian menggunakan instrumen wawancara mendalam kepada 11 informan yang dilakukan di Provinsi Banten pada bulan Januari-Juni 2017. Analisis data kualitatif menggunakan analisis konten. Hasil penelitian menunjukkan bahwa faktor lingkungan seperti keluarga, pergaulan, tenaga kesehatan, dan ketersediaan tempat prostitusi memicu permasalahan remaja. Lingkungan yang tidak mendukung mereka untuk belajar tentang seksualitas membuat mereka mencari informasi dari sumber yang tidak dapat dipertanggungjawabkan kebenarannya. Hal tersebut membuat remaja memiliki pengetahuan yang tidak tepat tentang kesehatan reproduksi remaja. Ketersediaan tempat-tempat prostitusi menjadi sorotan khusus bagi mereka yang dapat menyalurkan keingintahuan mereka dalam memenuhi hasrat seksualitas. Simpulan, permasalahan kesehatan reproduksi remaja di Provinsi Banten terdiri atas perilaku seks pranikah, kehamilan remaja, pernikahan remaja, persalinan remaja, penyakit seksual, dan perilaku seks menyimpang. Permasalahan tersebut muncul karena faktor lingkungan, pengetahuan, dan ekonomi keluarga.
\end{abstract}

Kata kunci: Kesehatan reproduksi, remaja, seksualitas 


\section{Introduction}

Adolescence is a period of transition from childhood to adulthood. Teenagers will experience physical, cognitive, and social-emotional changes according to their age. During this time, the reproductive organs begin to function so that they require attention in their reproductive health. ${ }^{1}$

Based on the 2012 Indonesian Demographic and Health Survey (IDHS), premarital sex behavior in adolescents is quite high. This results based on an unhealthy dating style that can lead to premarital sex. Premarital sex occurs out of curiosity ( $57.5 \%$ of men), instinct $(38 \%$ of women), and forced by a partner (12.6\% of women). They reflect the lack of understanding of adolescents about the risk of sexual relations and the ability to reject relationships that they do not want. ${ }^{2-4}$

Condom use in adolescents is also the center of attention. The percentage of condom use in adolescents has increased from $18 \%$ in 2007 to $21.8 \%$ in 2012 . Increasing condom use will increase the risk. The risks posed are unwanted pregnancies and sexually transmitted infections. This amount is a concern for the Banten region because $4.5 \%$ of the total teenage population is in Banten province. ${ }^{5}$

The problems faced by adolescents at this time can affect the number of maternal and child mortality. Out of wedlock sex problems are happen in adolescents that cause unwanted pregnancies and increase the number of child marriages (adolescents). These pregnancies can pose a risk of death because of abortion, complications of pregnancy, and childbirth. The risk of free sex can also cause sexually transmitted infections (STIs) or HIV/AIDS in adolescents. ${ }^{6}$ The proportion of married age in adolescents based on sex shows that women are twice as big as men. In 2012, one in one hundred girls aged 15 years in Indonesia became a mother. ${ }^{5}$

Banten province is the fifth most important and most populous region in Indonesia. The population increase in Banten province mostly comes from migrant residents. This condition influenced because of north Banten (Tangerang area) is a hinterland area for the Special Capital Region of Jakarta. Banten province is also an industrial area that is supported by its strategic location in the distribution both by land, sea, and air. The existence of Merak port as an existing sea transportation route in the Sunda Strait and Soekarno Hatta International Airport. ${ }^{7}$
The purpose of this study was to determine the problems in adolescents related to reproductive health in Banten province.

\section{Methods}

This study used a qualitative design and conducted in Banten province in January-June 2017. The participant selected using a purposive sampling technique. Data retrieval was done by interview method directly (face to face) to the informant. Interviews were conducted using interview guideline instruments made by researchers. The data collecting instrument consists of 5 (five) questions. The instrument developed based on the theme during the in-depth interview.

The informants used in this study were 11 people who lived in Banten province. Informants came from users of peer counseling services (counselors and counselees), health workers (obstetricians or gynecological obstetricians, pediatricians, and midwives) who provided reproductive health services, psychologists who provided adolescent counseling services, the National Population and Family Planning Board (Badan Kependudukan dan Keluarga Berencana Nasional/BKKBN), the Health Office, and the Information and Counseling Center for Youth (Pusat Informasi dan Konseling Remaja/PIK R).

This research had obtained a feasibility permit from the Health Research Ethics Committee of the Faculty of Medicine, Universitas Padjadjaran Bandung with an ethical approval letter number: 47/UN6.C1.3.2/KEPK/PN/2O17.

\section{Results}

The strategic location of Banten province is close to the National Capital to be a concern to pay more attention to the development of adolescent health. Based on the in-depth interviews, the problems in adolescents related to reproductive health in Banten province are as follows.

The cases of premarital sex behavior are still high in Banten province. Based on data recorded in the Banten Province Prevention of AIDS Commission that $40 \%$ of premarital sex practices in commercial sex workers in Banten province are adolescents aged $16-20$ years. ${ }^{8}$ Many stated that contributors to cases of premarital sexual behavior were carried out by urban teenagers. Free adolescent association in urban areas is one of the main factors causing it. However, cases of premarital sexual behavior do not only occur in 
urban areas but also villages. Premarital sexual behavior will bring new problems for adolescents, namely the occurrence of pregnancy outside of marriage.

"....in a village that I live for sure every year at least five children (junior high school-high school age) are pregnant out of wedlock...." (R3)

A lack of knowledge influences the premarital sexual behavior in adolescents in the Banten province. Teenagers perceive that sexual relations will make the body healthy because the calories produced are higher than the traditional exercise. Sexual desire that channeled makes them happy. They also stated that sexual intercourse did not cause pregnancy.

"....even though it's like sex (sexual intercourse) the calories are so much better than exercise, fun, and not necessarily pregnant too... from the searching in the web." (R1O)

The knowledge about sexuality is influenced by ignorance in seeking information sources that can be justified. They will ask friends who might not know and even search for themselves through the internet according to the current digitalization era. Teenagers quickly get information through the internet from various authors. However, not all authors who provide information on the internet are experts in their fields.

Another factor that causes problems in adolescents is the environment. The environment around adolescents does not support sexuality. The sexual education approved in the school environment. However, it has not supported by the family environment. The family environment is vital because parents usually get less critical information about sexuality education. Sexuality education in adolescents considers as taboo by parents. They believe talking about sexuality with teenagers is similar to teaching them to do unwanted things. ${ }^{9,10}$

"....in Banten the old people protest when sexuality taught in school." (R1o)

In Banten province, it is also easy to find places of prostitution. The prostitution place usually concealed as a place of lodging (hotel), the entertainment place (karaoke), eating place (restaurant), and massage parlor. Everyone can enter the areas which offer an affordable price.
This environment makes it easier for teens to channel their curiosity to sexuality.

"....I know such places start from the lowest and most expensive price in this place. They are even giving snacks (the commercial sex workers)." (R3)

Teenage pregnancy is a pregnancy that occurs at the age of under 20 years, regardless of married or unmarried women. ${ }^{11}$ The adolescent pregnancy in Banten province is still high. The high number of pregnancy cases that occur in adolescents in Banten province sometimes is wanted. However, some are not wanted. An unwanted pregnancy is a pregnancy that occurs outside of marriage or pregnancy in teenagers who marry young. They have no plans to arrange births.

"....there are many (girls) under 20 years got pregnant. Some are out of wedlock, and some are married but don't want to get pregnant yet." $\left(R_{3}\right)$

Pregnancy in adolescents usually happened due to teenagers' lack of knowledge about the pregnancy process and how to prevent pregnancy. They assume that having a relationship is okay, and there will be no consequence of pregnancy. Teenagers also do not understand about puberty phases, the fertile period, and the dangers of pregnancy in adolescents.

"There is someone who does not know what the fertile period is. We think that if sexual intercourse did only once, there no risks for health." (R1o)

Teenagers who do not want pregnancy who are sexually active have usually lack information about contraception. Contraceptive information has provided by health workers only to those who are married. Health workers still hesitate in introducing contraception in adolescents. The unwanted teenage pregnancy cases in the Banten province occur mostly because of the pregnancy outside marriage.

"....he said he couldn't use a condom. Can you get married because you are pregnant? I think because it's for teenagers I tell the simple explanation, not long like those who are married...." (R3) 
The teenage marriage occurs before the age of 18 years. ${ }^{12,13}$ This case is still high in Banten province both in villages and in urban areas. The number of adolescent pregnancy in rural areas is $13 \%$ higher than in urban areas $6 \%$. Marriage occurs, and because of that, many teenagers do not continue their education or drop out of school. One of the economic factors of the family influenced them not to continue school. They cannot get good jobs other than traders, laborers, or farmers. They have no choice but to marry. They assume that by getting married, there will help make a living.

"High school dropout rates are high, so where are you going if you don't get married." (R3)

The Banten government always improves the quality of education by providing educational facilities and infrastructure. Access to education (schools) is added to accommodate school-age residents according to their education level. However, based on the Banten Province Regional Statistics Report 2016, school enrollment rates are still low in the age of $16-18$ years.?

Teenage marriage also occurs because of something unwanted like pregnancy outside marriage. The high number of premarital sex cases will have an impact on one of them is adolescent marriage. This marriage will add to the burden on parents both psychologically and economically.

"....still in school, but reportedly was married because of 2 months pregnant." (R4)

Adolescent labor is labor that occurs under the age of 20 years. Childbirth is a health problem without seeing pregnancies outside of marriage or marriage. One of these teen births occurs because the knowledge of adolescents about the dangers of giving birth at an early age is still lacking. Childbirth in Banten province is still high. Youth or young childbirth is at risk of bleeding. Bleeding cases account for death in the mother. The high rate of delivery is comparable to the high maternal mortality rate (MMR) in Banten province. The total maternal mortality in Banten province in 2016 recorded at 240 people. ${ }^{14}$ One of the causes of death is one that is too young to give birth.

"Many are still 15 years have children, 16 years have children, 19 years have children. I don't know what the complications are, and then the parents complain about me in trouble.” (R1)

Adolescent childbirth indirectly has an impact on their parents. Teenagers still enjoy playing with their friends, and many of their children neglected, so their parents will become caregivers and meet their economic needs. The children become a burden on the adolescent parents.

The significant problem of sexually transmitted diseases such as sexually transmitted infections (STIs) and HIV/AIDS is also a problem that exists in adolescents in Banten province. One of these problems arises because of the consequences of premarital sex. Teenagers do not understand the signs and symptoms of sexually transmitted diseases. They consider the symptoms of STIs as a form of food poisoning.

\section{"....STIs he said it was sore throat...." (R3)}

Information on sexually transmitted diseases (STDs) is already conducted regularly in Banten province. The Health Office and the BKKBN share information through the young health program (pelayanan kesehatan peduli remaja/PKPR) and PIK R. However, there are still teenagers who come to health services with STDs who do not understand the methods of transmission and prevention on them.

"....teenagers are coming to the hospital... already with HIV." (R5)

Abnormal sexual behavior is also a problem for teenagers found in Banten province, for example, homosexuality. ${ }^{15}$ Homosexuality is a personal, emotional, and sexual attraction to people of the same sex.

"....men like men, there are also fellow women... He does have experiences." (R11)

\section{Discussion}

Based on the results of the study it was found that adolescent reproductive health problems in Banten province included premarital sexual behavior, teenage pregnancy, teenage marriage, youth delivery, sexually transmitted diseases (STIs and HIV/AIDS), and abnormal sexual behavior. These problems exist because they influence each other. The issue of adolescence did not only in urban areas but also in villages.

The problems of adolescents in Banten has 
influenced by the knowledge factor. The result has following the results of Iswarati's $\mathrm{s}^{16}$ research that stated the knowledge of adolescents about the fertile period in Banten province was very low at $8.4 \%$. They did not understand that unprotected sexual relations would lead to pregnancy and the risk of sexually transmitted diseases (STIs and HIV/AIDS).

Adolescents had unprotected premarital sexual intercourse without considering the impact or the risk so that an unwanted pregnancy occurs. A pregnancy that occurs can continue to unsafe abortion. Pregnancy at a young age has the chance of anemia, hypertension, eclampsia, premature birth, low birth weight (LBW), infection, and labor bleeding that can increase maternal and infant mortality. ${ }^{3,17,18}$ In young mothers who gave birth, but were not ready physically and mentally and were supported by inadequate nutritional intake will cause intergenerational cycle of growth failure. ${ }^{3,17}$

Teenagers would prefer to seek reproductive health information through digital media rather than going to health workers. The internet was a place that is considered capable of meeting their needs without any "bad labels" from other people, especially for those who are sexually active. However, they did not realize that the information obtained from the internet could not all be true. Rohmayanti et al. ${ }^{19}$ in their study revealed that the youth-friendly health services were not optimal resulted in dissatisfaction and mistrust of teenagers towards health workers. They were worried that the results of their medical examinations would be available for other people. The condition occurs due to a lack of proper communication to establish good relations between health workers and adolescents.

The environmental factors also influenced the problem of adolescents in Banten province. The family environment did not support their children to learn about sexuality in school. The family also did not teach teenagers about the importance of sexuality knowledge. The family environment was a significant hindrance in shaping adolescent behavior. The family closest to teenagers was parents. Teenagers who did not get sexual education from their parents, usually engage in risky sexual behavior earlier..$^{20,21}$

The family factors also influenced child-age marriage in adolescents in the Banten province. Many parents agree to early marriage in hopes of achieving social and financial security for their children after marriage. Fadlyana and Larasaty's $\mathrm{s}^{22}$ research found that the reason for early marriage is often due to the fear of an extramarital pregnancy due to the promiscuity of teenagers.

The family economy also influenced marriage in adolescence. Some parents cannot afford to support their children to continue their education so that many teenagers drop out of school. ${ }^{13}$ The government has not reviewed the cost of school education to overcome this problem. The government was still trying to improve the quality of education by providing educational facilities and infrastructure. ${ }^{7}$ Those who do not continue their school did not have the opportunity to get good jobs. The jobs that they get is only low pay ones, which include farmers, laborers, traders, and household assistants. The type of employment encouraged them to marry young so that the family economy would be better. However, they did not think much about the impact of a young marriage for him and his family.

The age of adolescents was an age that is very concerned with relationships. They would be happier if they called "slang kids" so they could find as many friends as possible. However, the results of this study found that the social environment in adolescents could have a particular impact on them. Friends associating with lousy behavior will influence teens to follow it. Deviant behavior in question is smoking, alcoholic beverages, and drug abuse. This situation requires monitoring parents by creating quality relationships between children and parents. This relationship could help teens to choose friends with good behavior. ${ }^{23-25}$

Poor behavior from the environment would make the teenager misbehave. The problem had found in adolescents in Banten with the abnormal sexual behavior act because of bad experiences on sexual harassment. A study conducted by Fergusson et al. $^{26}$ in New Zealand states that sexual violence on children would harm their lives in the future. They can experience psychological, physical, and social health problems. Child sexual abuse would affect risky sexual practices in adolescents. ${ }^{27-29}$

The number of places of prostitution in Banten province made it easy to channel sexual desire. Risky sexual behavior (the use of prostitution) carried out by teenagers can be caused by his desire to channel intimacy desires, proof of selfesteem, and his tendency to experience. The 
adolescent problem behavior arises later on due to physical, sexual, or neglected childhood experiences..$^{30,31}$

\section{Conclusions}

Reproductive health problems in adolescents in Banten province consist of premarital sex behavior, teenage pregnancy, teenage marriage, youth delivery, sexually transmitted diseases, and abnormal sexual behavior. These problems arise due to factors of knowledge, environment, and family economic status.

\section{Conflict of Interest}

The author states that there is no conflict of interest.

\section{Acknowledgements}

The authors are grateful to Center for Quality Improvement of Human Resources for Health, Board of Development and Empowerment on Human Resources for Health, Ministry of Health Republic of Indonesia who have funding for the implementation of this research.

\section{References}

1. Sawyer SM, Afifi RA, Bearinger LH, Blakemore SJ, Dick B, Ezeh AC, et al. Adolescence: a foundation for future health. Lancet. 2012;379(9826):1630-40.

2. Statistics Indonesia; National Population and Family Planning Board; Ministry of Health of Republic of Indonesia; MEASURE DHS, ICF International. The 2012 Indonesia demographic and health survey. Jakarta: Statistics Indonesia (Badan Pusat StatistikBPS); 2013.

3. Pusat Data dan Informasi Kementerian Kesehatan Republik Indonesia. Situasi kesehatan reproduksi remaja. 29 Juni 2015 [cited 2017 August 15]. Available from: http://www.depkes.go.id/resources/ download/pusdatin/infodatin/infodatin\%20 reproduksi\%2oremaja-ed.pdf.

4. Badan Pusat Statistik. Kemajuan yang tertunda: analisis data perkawinan usia anak di Indonesia. Jakarta: Badan Pusat Statistik; 2015.

5. Adioetomo SM, Posselt $\mathrm{H}$, Utomo A,
McDonald P. The monograph series no. 2: youth in Indonesia [Internet]. United Nations Population Fund (UNPF) Indonesia. 2014 [cited 2017 September 15]. Available from: https://indonesia.unfpa.org/sites/ default/files/pub-pdf/BUKU_Monograph_ No2_Youth_in_Indonesia_ENG_O5_Lowres.pdf.

6. World Health Organization (WHO). Health for the world's adolescents: a second chance in the second decade. Geneva: WHO Press; 2014.

7. Badan Pusat Statistik Provinsi Banten. Statistik daerah Provinsi Banten 2016. Serang: Badan Pusat Statistik Provinsi Banten; 2016.

8. Komisi Penanggulangan AIDS Provinsi Banten. 40 persen PSK di Banten berusia belia [Internet]. JPNN.com. 2012 [cited 2017 August 16]. Available from: https://www. jpnn.com/news/40-persen-psk-di-bantenberusia-belia.

9. Lukolo LN, van Dyk A. Parents' participation in the sexuality education of their children in rural Namibia: a situational analysis. Glob J Health Sci. 2015;7(1):35-45.

10. Nghipondoka-Lukolo LN, Charles KL. Parents' participation in the sexuality education of their children in Namibia: a framework and an educational programme for enhanced action. Glob $J$ Health Sci. 2016;8(4):172-87.

11. World Health Organization (WHO). Adolescent pregnancy: issues in adolescent health and development. Geneva: WHO; 2004.

12. World Health Organization (WHO). Child marriages: 39 ooo every day [Internet]. WHO.int. 2013 [cited 2018 August 15]. Available from: https://www.who.int/ mediacentre/news/releases/2013/child_ marriage_20130307/en/.

13. Khusna NA, Nuryanto. Hubungan usia ibu menikah dini dengan status gizi balita di Kabupaten Temanggung. JNC. 2017;6(1):110.

14. United States Agency for International Development (USAID) Jalin. Kematian ibu dan anak di Provinsi Banten tinggi [Internet]. kabar-banten.com. 2018 [cited 2018 December 2]. Available from: https:// www.kabar-banten.com/kematian-ibu-dananak-di-provinsi-banten-tinggi/. 
15. Dinas Kesehatan Provinsi Banten. 2.175 pria di Banten suka sesama jenis [Internet]. dinkes.bantenprov.go.id. 2017 [cited 2018 December 12].Availablefrom: https://dinkes. bantenprov.go.id/read/berita/757/2175Pria-di-Banten-Suka-Sesama-Jenis.html.

16. Iswarati. Pengetahuan dan sumber informasi kesehatan reproduksi remaja di Indonesia. Manajerial. 2011;10(1):1-16.

17. Afifah T. Perkawinan dini dan dampak status gizi pada anak (analisis data Riskesdas 2010). Gizi Indon. 2011;34(2):109-19.

18. Gibbs CM, Wendt A, Peters S, Hogue CJ. The impact of early age at first childbirth on maternal and infant health. Paediatr Perinat Epidemiol. 2012;26(Suppl 1):259-84.

19. Rohmayanti, Qurrachman IT, Nisman WA. Health service by adolescents perspective in Magelang. Int J Res Med Sci. 2015;3(Suppl 1):S19-23.

20. Mmari K, Kalamar AM, Brahmbhatt $H$, Venables E. The influence of the family on adolescent sexual experience: a comparison between Baltimore and Johannesburg. PLoS One. 2016;11(11):e0166032.

21. Savioja H, Helminen M, Fröjd S, Marttunen M, Kaltiala-Heino R. Parental involvement, depression, and sexual experiences across adolescence: a cross-sectional survey among adolescents of different ages. Health Psychol Behav Med. 2017;5(1):258-75.

22. Fadlyana E, Larasaty S. Pernikahan usia dini dan permasalahannya. Sari Pediatri. 2009;11(2):136-41.

23. Van Ryzin MJ, Fosco GM, Dishion TJ. Family and peer predictors of substance use from early adolescence to early adulthood: an 11-year prospective analysis. Addict Behav.
2012;37(12):1314-24.

24. Simons-Morton B, Farhat T. Recent findings on peer group influences on adolescent substance use. J Prim Prev. 2010;31(4):191208.

25. Hiatt C, Laursen B, Stattin H, Kerr M. Best friend influence over adolescent problem behaviors: socialized by the satisfied. J Clin Child Adolesc Psychol. 2017;46(5):695-708.

26. Fergusson DM, McLeod GF, Horwood LJ. Childhood sexual abuse and adult developmental outcomes: findings from a 30-year longitudinal study in New Zealand. Child Abuse Negl. 2013;37(9):664-74.

27. Ports KA, Ford DC, Merrick MT. Adverse childhood experiences and sexual victimization in adulthood. Child Abuse Negl. 2016;51:313-22.

28. Nikulina V, Gelin M, Zwilling A. Is there a cumulative association between adverse childhood experiences and intimate partner violence in emerging adulthood? J Interpers Violence. 2017:886260517741626.

29. Adhia A, Gordon AR, Roberts AL, Fitzmaurice GM, Hemenway D, Austin SB. Childhood gender nonconformity and intimate partner violence in adolescence and young adulthood. J Interpers Violence. 2018:886260518770643.

30. Wilson HW, Widom CS. The role of youth problem behaviors in the path from child abuse and neglect to prostitution: a prospective examination. $\mathrm{J}$ Res Adolesc. 2010;20(1):210-36.

31. Reid JA. An exploratory model of girls' vulnerability to commercial sexual exploitation in prostitution. Child Maltreat. 2011;16(2):146-57. 